症例

非手術的療法によりイレウスを解除し，予定手術として

胆囊・十二指腸瘻を閉鎖しえた胆石イレウスの 1 例

帝京大学第 1 外科（主任: 四方湶一教授）

助手 测 野 研一 講師

\title{
A CASE OF GALLSTONE ILEUS PERFORMED ELECTIVE OPERATION FOR CHOLECYSTODUODENAL FISTULA AFTER RELEASING OBSTRUCTION SYMPTOM BY USE OF LONG INTESTINAL DECOMPRESSION TUBE
}

Ken-ichi KONO and Hisashi OKA

Department of Surgery, Teikyo University School of Medicine, Tokyo

(Director: Prof. Jun-ich SHIKATA)

胆石イレウスは比較的稀れで，術前診断の困雖な疾患であるとされている。また， レウスの解除と胆道系への手術を 1 期的におこならか否かについての問題がある.

我々は long tube (long intestinal decorpression tube)を用い,イレウス症状を解除 したのち，予定手術として胆衰摘出術を内㿉閉鎖術をおこなった胆石イレウスの 1 例を 経験した。

胆石イレウスにおけ忛る long tube の使用は，腸管内減王により腸管の運動性が回復し， 腸管のスバスムスがとれイレウスを解除することが期待できる。これは手術によるイレ ウス解除に比較し，侵襲が少なく，またイレウス解除後に補夜その他の術前準備を充分 におこなって，予定手術ができるといら点で有効であると考えられた．更に tube からの 選択的造影により閉塞部を造影することができ，結石を証明することす可能と思われる。

以上の事より，本症に対する long tube の使用は診断・治療の上で新たな方法になり らる事を示唆している。

\section{緒}

胆石イレウスの臨床上の興味は，本邦では比較的稀 な疾患であることもさることながら，その術前診断の むずかしさにあろう。これは原疾患としての胆石症， 䏹荎炎，それにひきつつく機械的イレウスとい5病態 の複雉さによるものと思われる。また，本症は比較的 高秢者に多く，しかも胆道系のフブローチをイレウス といら特殊条件下で 1 期的におこなうことは，侵翼が 大きいことから比較的死亡率が高いとされてい $3^{1 / 2)}$.

我々は long intestinal decompression tube (以下 long tube）をもちいイレウスを解除したのち，予定手 術として胆票摘出術と内瘦閉鎖術をおこなった胆石イ
レウスの 1 例を程験した。

\section{症例}

症例：46歳，主婦

主訴：呕吐, 左上腹部痛

家族歴：特記すべきことなし

既往歴：䄪 6 年前に一度，右季助部痛が出現し，投 薬により症状が緩解した。開腹手術の既往はない。

現病歷：昭和 52 年 5 月 10 日より食欲不振, 全身倦急 感が出現した。一週間後, 左季肋部痛と呕吐が出現し たが，排便は入院前日まであった，近医で治㞠を受け たが，上記症状が軽快しないため当科を受診し，直ち に入院した。

入院時現症：体格中等度，栄盖普通，意識明瞭，血 
血 液

\begin{tabular}{|c|c|c|c|}
\hline ヘモグロビン & $14.9 \mathrm{~g} / \mathrm{d} \Omega$ & ビリルビン & $1.0 \mathrm{mg} / \mathrm{dl}$ \\
\hline 赤血球数 & $460 \times 10^{4}$ & $\mathrm{Na}$ & $140 \mathrm{mEq} / \mathrm{I}$ \\
\hline ヘマトクリット & $44.9 \%$ & $\mathrm{~K}$ & $3.7 \mathrm{mEq} / 1$ \\
\hline 白血 球 数 & 4600 & $\mathrm{Cl}$ & $102 \mathrm{mEq} / \mathrm{s}$ \\
\hline 血小板 数 & $30.8 \times 10^{4}$ & GOT & $12 U$ \\
\hline 出 血 時 间 & $2^{\prime} 30^{\prime \prime}$ & GPT & $14 U$ \\
\hline 凝 固 時 间 & $9^{\prime} 30^{\prime \prime}$ & Al-P & 5.10 \\
\hline & & TTT & $0.4 \mathrm{U}$ \\
\hline & & ZTT & $4.4 \mathrm{U}$ \\
\hline 白 & $(-)$ & LDH & 206 \\
\hline 祒 & $(-)$ & LAP & $101 \mathrm{U}$ \\
\hline ウロビリ & $(-)$ & T.P & $6.4 \mathrm{~g} / \mathrm{d} \ell$ \\
\hline 沈 查 & 異常なし & $A / G$ & 1.0 \\
\hline
\end{tabular}

心軍图所見

異常なし

压 $120 / 60 \mathrm{mmHg}$, 脈拍 $92 /$ 分で緊張良好, 眼睮結膜に筫 血なく，眼球結膜に黄疸なし，舌苔軽度，胸部理学的 所見正常, 肺肝境界第 6 肋間, 左上腹部に压痛がある が筋性防禦はなく，ブルンベルグ徵候陰性.

入院時検查所見：(表 1 )

入院後経過：入院時の腹部単純 $\mathrm{X}$ 線写真では扗張
した小腸ガス像および小腸水面像を認めたが，白血球 数の増加，体温の上昇がなく，腹膜刺激の所見がない ことから単純性イレゥスと考えられた（图 1).

そこで long tubeにより腸管内吸引減圧をおこなっ た，減王効果は著明で小腸ガス像は消失した。 その後 tube の先端は大腸内に先進した。 また long tube 挿入 時, tube の先端確認のため注入した造影剂で染められ た結石の輸郭を左下腹部に認めた(図 2 )。この結石は 第 5 病日に肛門から排泄された。 $3.3 \times 2.2 \times 3.3 \mathrm{~cm}$ の ビリルビン結石で接面形成を認めた（図 3 ).

イレゥス解除後の上部消化管造影で十二指腸球部に 上方に突出する異常陰影を認めた（図 4)

以上の所見から本症例は胆衰・十二指腸瘦より消化 管内に落下した結石による胆石イレウスと考えられ た.

イレウス症状が解除したので, 補液, その他の街前 準備を充分におこない第11病日に予定手術をおこなっ た.

手術所見上腹部正中開にて開腹，腹水は認めず，す でに腸管の拡張はない，肝床部に十二指腸が胆重を挖

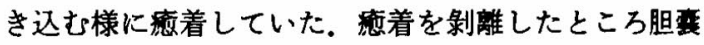
と十二指腸球部に内掼を形成していた（図 5)

術後経過：経過は順調で, 第39病日に治痿退院した。

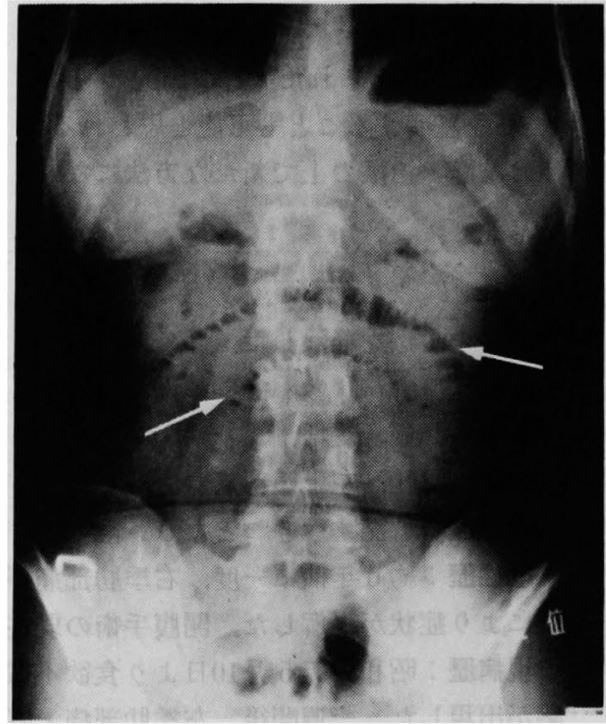

(A) 立位背腹方向

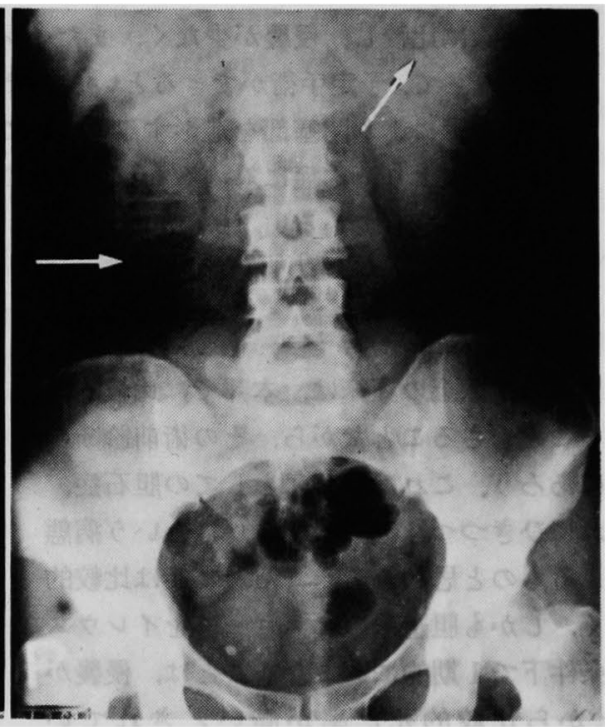

（B）背臥位背腹方向

図 1 腹部単純 $\mathbf{X}$ 線写真

立位（A）では上腹部に大きな 2 個の水面像をともなった小腸ガス像（矢印）が認め られる。背臥位（B）では拡張した小腸ガス像（矢印）を認める， $\mathrm{S} / \mathrm{L}_{1}=1.25$ 


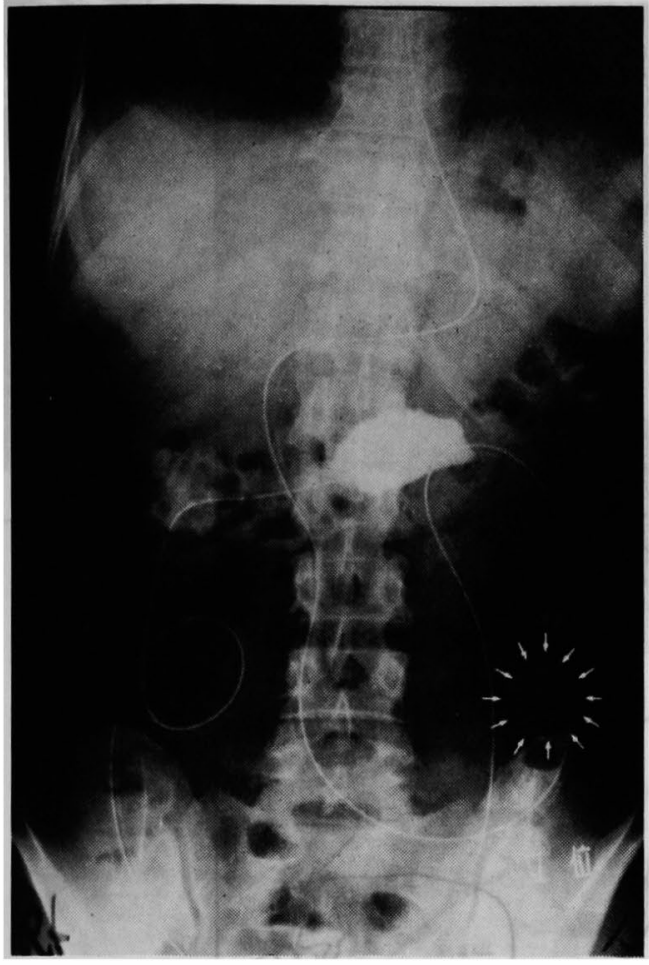

図 2 腹部単純 $\mathbf{X}$ 線写真

long tube の先端の ballon は横行結腸に到達してい る. 小腸ガス像ははとんど消失しており，造影剂で 表面を染められた結石の輪郭を左下腹部に認める. （矢印で围まれた部分）

患者は術後 4 年間にわたり外来にて follow up して いるが, その間, 血液生化学検查では異常を認めず. 腹部に関する愁訴はなんら認めていない.

考察

胆石イレウスとは胆栾・胆管結石が正常な胆管開口部 およびその他の異常経路を通って腸管内に移行し，そ れによって腸管の閉塞がおこることをいう. その発生 頻度は極めて低く，イレゥスの総数に対する本症の発

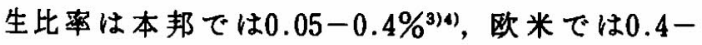
$5.0 \%{ }^{516)}$ とされ，また胆石症の総数に対する発生比率 は前者では $0.5 \%$ ，後者では $0.3 \%$ ?) と報告されてい る. 当数室ではイレウスの $0.4 \%$, 胆石症の $0.5 \%$ に発 生している。

胆石イレウスにおいて結石が正常経路を通って腸管 内へ落下寸るのはKasaharaらによると14\%であ り"，むしろ胆衰と腸管との異常経路を通過した結石 によっておこることが多い.

内瘦形成の好発部位はWaggonerらによると胆

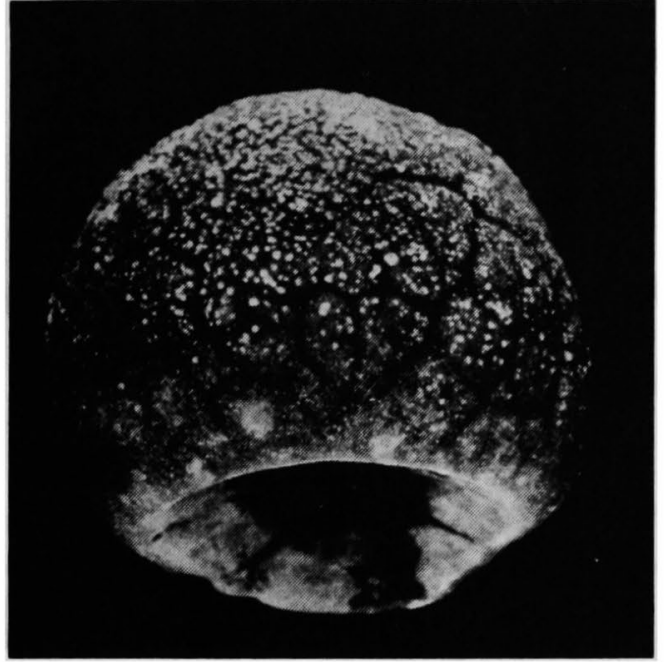

图3肛門より排泄された結石

大きさは $3.3 \times 2.2 \times 3.3 \mathrm{~cm}$ のビリルビン結石で接 面形成がある.

变・十二指腸瘦が $51 \%$ と最も多く，その他胆变・結腸 瘦 $21 \%$ ，総胆管・十二指腸瘦19\%で，まれなタイプと して胆震・胃瘦, 総胆管・胃㾝, 胆要・総胆管瘦があ ると報告している められた。

腸管内に落下した結石のすべてがイレウスをおこす わけではなく, Raifordによると, 腸管内に落下した結 石の約 $10 \%$ 以下にイレウスが発生するとしている また落下した結石の閉塞部位は, Fossらによれば約 60\%において回腸末端部であると報告しているが7)， その原因は回腸末端部の管腔が狭く，かつ蠕動が弱い ことにあろ 5811121. しかし，本症例では閉塞部位が不 明であり,腹部単純 $\mathrm{X}$ 線写真上であ入院時には結石像 を証明することはできなかった。

胆琵疾患を思わす既往は本症例でる認められたが， Day らによると本症の $47 \%$ に上腹部痛や黄㾝などの 胆变疾患を思わす既往を有するとしておりり"11，胆变疾 患の既往のないものは胆石イレウスの約 $15 \%$ 程度にす ぎない．このことから考えると，胆藏疾患の既往をる ち，かつ開腹手術の既往のない中年以上の女性に执こ る単純性イレウスは, 本症も考虑に入れる必要がある.

本症の診断にはX 線学的検索が有力な手段とされ ているが, Rigler らは腹部単純 X 線写真による胆石イ レウスの診断基準を次の如く定めている．1．胆道内 空気像，2．腸管内結石像，3．イレウス像，4．結 石の位置変化，である ${ }^{13)}$. しかし，これらの所見が全て 

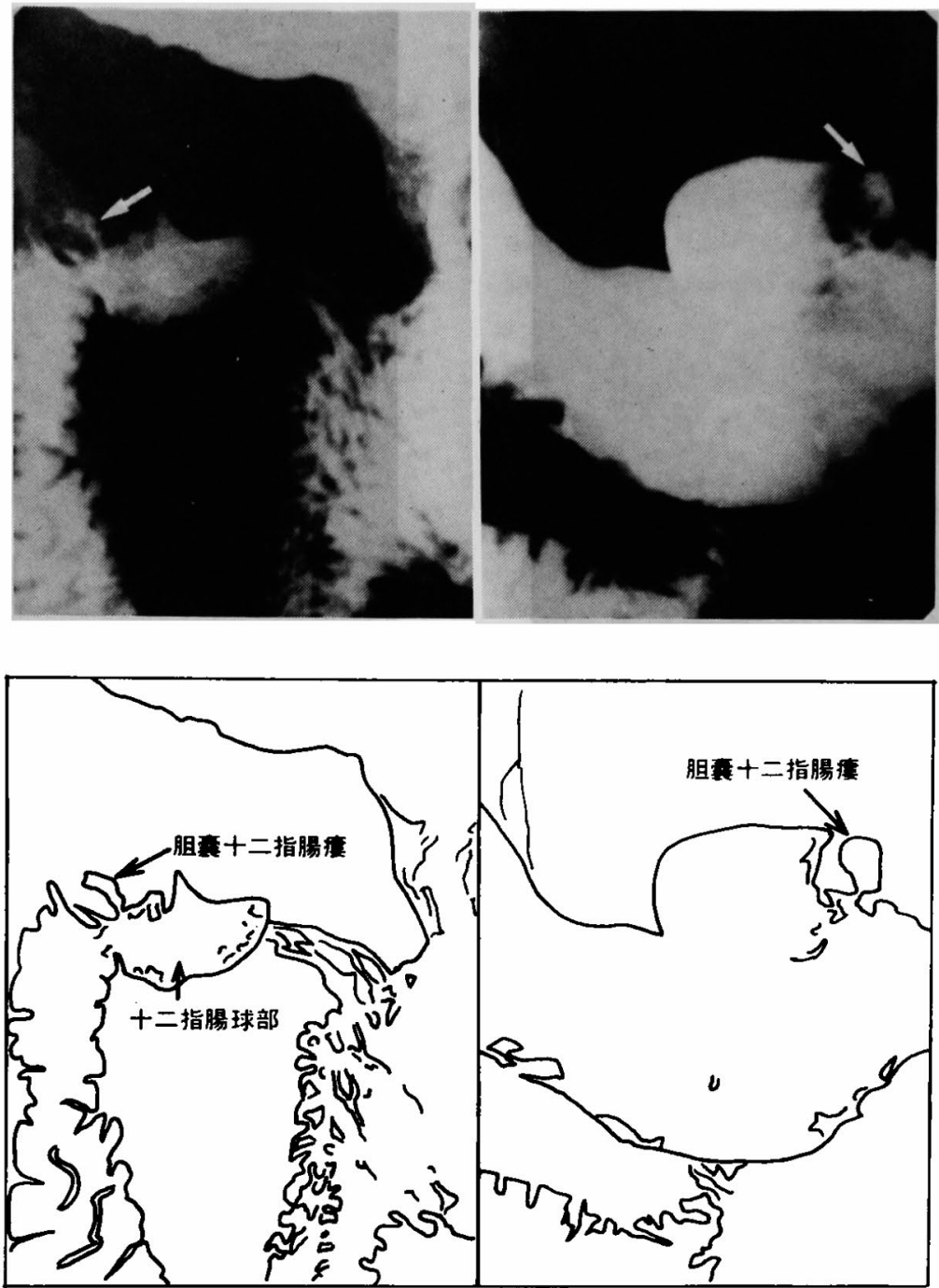

図 4 上部消化管造影

(A)：背臥位第 1 斜位

(B)：腹臥位

十二指腸球部に胆萑内に突出した異常陰影を認め, 胆落・十二指腸瘦を思わせた。

そろらことは稀れであり，本症例ですイレウス像を認 めたにすぎなかった。

その他の術前診断法として，上部消化管造影による 胆蓄内人の造影剂の逆流 ${ }^{14)}$ ，内視鏡による内瘦の証明 などがある15). 本症例では long tube 挿入時, 先端確認 のため注入した造影剂により，造影剂で染められた結 石の輸郭を認めた。

本症の治療について, 上田らは初回手術時にイレウ スの解除と胆道系の手術を同時におこなった時の死亡
率は18.8\%で，イレウスの手術的解除のみに留めたす のの14.3\%に比較し死亡率は高いと報告している2. したがって本症例の如く，イレウスをlong tube よって非手術的に解除すれば，手術によるすのより侵 部が少なく，死亡率の低下にもつながると考えられる。

一方，イレウスの解除のみでは胆石イレウスの再発 例が $5 \%$ に認められ6), 胆道系の癌の発生が $15 \%$ 認められるとの報告があり11)，我々はイレウス解除後 の胆道系への手術は，おこならべきたと考えた。 

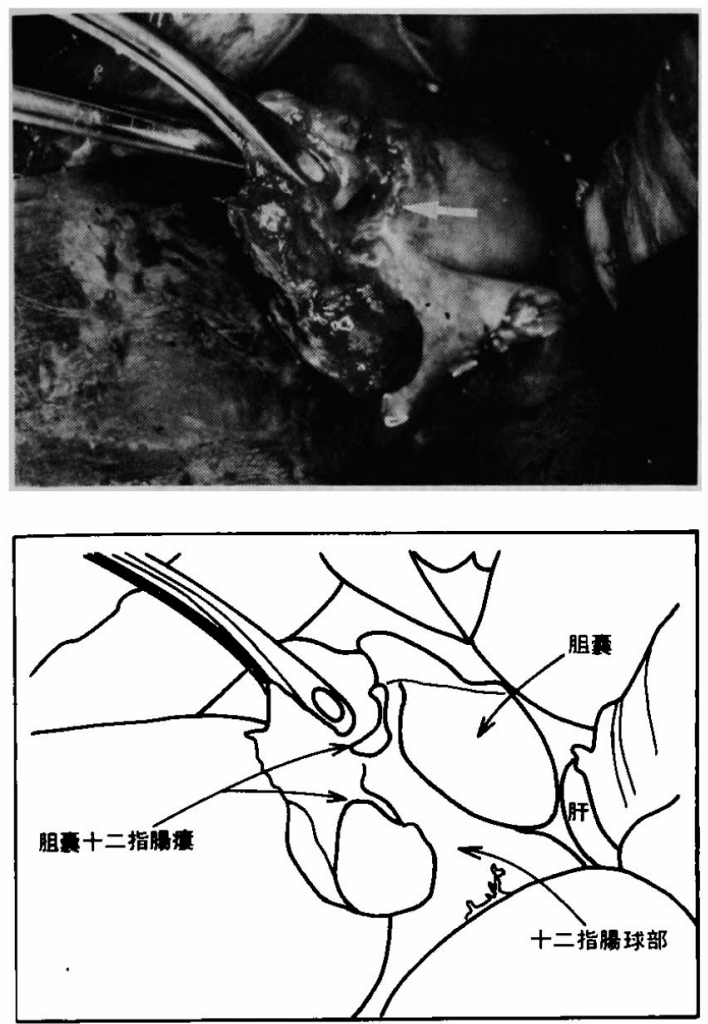

図 5 手術所見

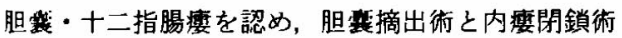
を施行した。

long tube は操作上の煩雑さはあるが, 次の利点を有 する，1，鼓腸を緩解する，2，腸管内造影を扣こな いらる，3．開腹操作が容易となる，4，開腹手術を さけることができるかるしれない16)，である。

本症に限らす開腹手術の既往のない単純性イレウス に㧍ける long tube の使用は, イレウス症状の解除の みでなく訩断上の意義も大きい.

胆石イレウスの発生が結石の大きさによる器質的因 子のみでなく機能的因子，すなわち結石の刺激による 腸管のスパスムスなどが関与していることを考虑すれ ば, long tube によって腸管内を吸引減圧することは腸 管の運動性が生理的状態に帰することになり，腸管の スパスムスがとれイレウスが解除される．更に，選択 的造影により閉塞部を造影することが可能であり，結 石を証明できる可能性が強いと考えられる，従って， 本症に対する long tube の使用は, 術前診断のみなら ず治療の上に拈いても一助となりらる可能性を示唆し ている.

\section{結語}

我々の経験した胆石イレウスの症例を報告し，若干 の文献的考察を加えた。

本症例は非手術的療法によりイレウスを解除し，予 定手術として胆变摘出術と内㾇閉鎖術を掞こないえた 症例である。

稿を終るにあたり、ご指左・ご校閲を頂いた帝京大学第一 外科教室の四方淳一教授に感謝いたします。

本論文の要旨は第149回日本消化器病学会関東甲信越地 方会において発表した。

\section{文献}

1）高田秀穂, 高村宙二, 坂田 道他：胆石イレウス 本邦報告121例を中心に. 消化器外科 $4 ： 341-348$, 1981.

上田耕臣, 川島宽昭, 勝田仁康他：胆石イレウスの 1 例. 和歌山医学, $31: 215-222,1980$ 。

3) 岡田耕平：本邦イレウス症例の㤝計的観察 (No. 15）腸管内異物によるイレウス402例について，日 医大誌，24：76, 1957.

4）三穂乙実，佐々木優至，松島孝雄他：胆石イレウ ス。 日消外会誌，9:665-671，1976.

5) Eisenman, J.I., Finck, B.J. and O'Loughlin, B. L. : Gallstone ileus. A review of the roentgenographic findings and report of a new roentgen sign. A.J.R., 101 : 361-366, 1967.

6) Kvist, E. : Gallston ileus ; a retrospective study. Acta Chir. Scand., 145 : 101-103, 1978.

7) Foss, H.L. and Summers, J.D. : Intestinal obstruction from gallstone. Ann. Surg., 115: 721 $-735,1942$.

8) Kasahara, Y., Umemura, H., Shiraha, S., et al.: Gallstone ileus: Review of 112 patients in the Japanese literature. Am. J. Surg., 140: 437 $-443,1980$.

9) Waggoner, C.M., LeMone, D.V. and Charles, M. : Clinical and roentgen espects of internal biliary fistulas (report 12 cases). Radiology, 53 : 31-41, 1949.

10) Raiford, T.S. : Intestinal obstruction caused by gallstone. Am. J. Surg., 104 : 383-394, 1962.

11) Day, E.A. and Mark, C.: Gallstone ileus: Review of the literature and presentation of thirty-four new cases. Am. J. Surg., $729: 552$. 558, 1975.

12) Glenn, F. and Mannix, H. Jr.: Biliary enteric fistula. Surg. Gynecol. Obstet., 105 : 693-705, 
1957.

13) Rigler, L.E., Borman, C.N. and Noble, J.F. : Gallstone obstruction : Phathogenesis and roentgen manifestations. J.A.M.A., 117 : 1753-1759, 1941.

14) Cooperman, A.M., Dickson, E.R. and Remine, W.H. : Changing conceps in the surgical treatment of gallstone ileus: A review of 15 cases with emphasis on diagnosis and treatment. Ann. Surg., $167: 377-383,1968$.

15）池田靖洋，田村亮一，岡田安浩：内視鏡にて锶察 された十二指腸乳頭近房の総胆管十二指腸度一胆 石の自然脱落機序に関する考察一胃と腸，8： 1489-1502, 1973.

16）四方淳一：イレウスの治療における long tube の 使用について.医学のあゆみ, $98: 823-830,1976$. 